\title{
Microalgae as a potential source of single-cell proteins. A review
}

\author{
Abakoura Barka, Christophe Blecker \\ University of Liège - Gembloux Agro-Bio Tech. Food Science and Formulation Laboratory. Passage des Déportés, 2. \\ B-5030 Gembloux (Belgium).E-mail: abak_gada@yahoo.fr
}

Received on June 14, 2015; accepted on May 23, 2016.

Introduction. Microalgae can be considered as one of the most reliable natural sources of nutrients and other valuable substances that could satisfy the growing needs in food and energy. In this review article, the global potential for the use of microalgae and the protein content of a number of microalgae is examined with a brief description of the microalgae species. Literature. Despite the high protein content and the presence of other valuable substances in microalgal biomass, microalgae mass production is still at its embryonic level. Microalgal proteins exhibit good nutritional, functional and technofunctional properties when compared to some conventional protein concentrates.

Conclusions. There is therefore a need for the mass production of microalgae to be boosted by public and private institutions in order to avoid protein shortages.

Keywords. Nutrients, protein content, biomass, production.

Les microalgues comme une source potentielle de protéines d'origine unicellulaire (synthèse bibliographique)

Introduction. Les microalgues peuvent être considérées comme une des sources fiables de nutriments et d'autres substances de valeur pouvant satisfaire le besoin croissant en aliment et en énergie. Dans la présente revue, le potentiel global en microalgues, la teneur en protéines et une brève description de certaines espèces de microalgues sont présentés.

Littérature. Malgré leur teneur élevée en protéines et en d'autres substances de valeur, la production industrielle des microalgues est encore à l'état embryonnaire. Les protéines des microalgues présentent de bonnes propriétés nutritionnelles, fonctionnelles et technofonctionnelles lorsqu'elles sont comparées aux protéines conventionnelles.

Conclusions. La production des microalgues doit donc être encouragée par les autorités publiques et privées afin d'éviter les pénuries de protéines.

Mots-clés. Nutriments, teneur en protéines, biomasse, production.

\section{INTRODUCTION}

The search for new protein sources to supplement the existing conventional sources in order to fill the so called "protein gap" has been the route of inspiration for many scientists for years.

Single-cell protein (SCP) refers to protein extracted from pure or mixed cultures of algae, yeast, fungi or bacteria used as a substitute for the conventional protein sources exploited for human and animal consumption. Proteins are macromolecules with a complex chemical structure, and this complexity is the basis of their multiple physiological, morphological, and technological uses. Proteins can be used as sole protein concentrates or may be integrated into processed foods. In the latter case, each constituent of the processed food product plays a specific role, be it nutritional, technological or functional. Knowledge of the technofunctional and nutritional properties of proteins is therefore a prerequisite for their proper utilization in the food industry.

Microalgae have been identified as one of the most reliable sources of protein and were a source of interest to the majority of those involved in agricultural and food domains during the second half of the twentieth century. Some microalgal sources present a protein content higher than conventional animal or plant sources, e.g. the protein content of Spirulina paltensis is $65 \%$ higher than that of dried skimmed milk $(36 \%)$, soy flour $(37 \%)$, chicken $(24 \%)$, fish $(24 \%)$, beef $(22 \%)$ and peanuts $(26 \%)$ (Moorhead et al., 2011). Despite the tremendous variety of virtuous nutraceutical uses reported for substances derived from algal biomass (Simpore et al., 2006; Yamani et al., 2009), in addition to its high protein content, there is still much to be done in terms 
of algacultural implementation in order to make this foodstuff available at an affordable cost.

Of the more than 30,000 microalgae species, fewer than 10 are commercially produced (Gouveia et al., 2008). Despite the fact that some of these microalgae species have been historically used as food, their industrial production is not up to the level that might be expected.

In this review, emphasis will be placed on some of the microalgae species that are currently being industrially produced and/or those that present a relatively high protein content. The global microalgal potential, the protein content of some microalgae species, and the technofunctional and nutritional properties of these algal proteins will be presented, as reported in the literature.

\section{GLOBAL MICROALGAE PRODUCTION POTENTIAL}

Microalgae (unicellular organisms) and macroalgae (multicellular organisms) belong to the large algae group made up of photosynthetic organisms. They are known to have appeared on Earth 3.5 billion years ago and they are considered to be the first form of life (Margulis, 1981). Like terrestrial plants, algae are autotrophic organisms; however, they lack stems, leaves, flowers, and are rootless. Among the microalgae, while some are eukaryotic and commonly identified as algae, others are devoid of a membranebound nucleus (prokaryotes, cyanobacteria) and bear an intermediate structure between bacteria and plants. Microalgae have a higher level of productivity than traditional crops and can be grown in climatic conditions, such as desert and coastal areas (Christaki et al., 2011). Their production yield is not only high but also environmentally friendly. Marshall ${ }^{1}$ (2007) cited by Christaki et al. (2012) reported that microalgae are the most productive sources of nutrients in the world. There is growing interest in microalgae, due to their ability to concentrate essential nutrients and functional substances.

Microalgae production initially mistakenly focused its marketing efforts on health foods, which represent a small market and cannot instigate a large demand. This orientation has been found to be responsible for the limited development of the industrial mass production of microalgae (Richmond, 2004). Yet, many microalgae (such as Spirulina, Chlorella, Dunaliella, Scenedesmus), when correctly processed, have an attractive taste and could thus be incorporated into many types of food. This would lead to an increase

${ }^{1}$ Marshall H., 2007. Micro-algae as a superfood source: phytoplankton for future nutrition. Vegetarian, 1-2. in the demand for microalgae (Richmond, 2004). The daily production rate of protein-rich microalgae cell mass presents an annual yield of some $250 \mathrm{t} \cdot \mathrm{ha}^{-1}$, i.e. several times that of any agricultural commodity (Richmond, 2004).

Mass production of microalgae can be carried out outdoors or in bioreactors, under optimal conditions. Microalgae provide an opportunity to exploit the underutilized arable lands and oceans without reducing the agricultural production surface, which needs to be supplemented in order to feed the growing global population. The use of microalgae in waste water treatment, for biofuel production and for atmospheric carbon dioxide sequestration (owing to their photosynthetic activities) is also boosting the demand for mass production.

Chlorella is among the most ancient microalgae species used in the human diet and its commercial utilization was introduced in 1961 by Nihon Chlorella Inc. in Japan (Iwamoto, 2004). Chlorella was initially cultivated for its use as a health food (it contains $\beta-1$, 3 -glucan, an immunoactive substance) and then in mariculture. The total amount produced in the 1990s was 2,000 t per year (Iwamoto, 2004). The mass production mode for Chlorella is either heterotrophic or mixotrophic. Production yield is higher in the latter production mode. In the mixotrophic production, acetic acid can be added to the medium as an organic carbon source in addition to the carbon dioxide. In the heterotrophic mode, carbon is supplied by the sole organic carbon source. However, Chlorella biomass obtained by heterotrophic mass production exhibits a superior quality for consumption as a health food; it is rich in valuable phytochemicals and does not present contaminants (Iwamoto, 2004). A study carried out by Praveenkumar et al. (2014) on Chlorella sp. modes of mass production (autotrophic and mixotrophic) revealed that a mixotrophic fed-batch cultivation with glucose and a supply of air in dark cycles showed the highest levels of biomass $\left(561 \mathrm{mg} \cdot \mathrm{l}^{-1} \cdot \mathrm{d}^{-1}\right)$ and fatty-acid methyl-ester $\left(168 \mathrm{mg} \cdot \mathrm{l}^{-1} \cdot \mathrm{d}^{-1}\right)$ productivity.

Arthrospira (Spirulina) sp. also has an historical background in human consumption. Spirulina maxima is recorded as having been used for human consumption, in dried cake form since 1521, in Tenochtitlan (modernday Mexico City) (Hu, 2004). The first commercial mass production of Spirulina began in the 1970s in Lake Texcoco. The use of Spirulina in the human diet also has a long history among the Kanembu tribes living around Lake Chad in Chad Republic. However, it remained unnoticed until the 1960s. Spirulina sp. is considered to be an obligatory alkalophile, with the maximal growth rate being obtained at $\mathrm{pH}$ 9.5-9.8 $(\mathrm{Hu}$, 2004). Its ability to thrive in a high $\mathrm{pH}$ environment limits the development of other microorganisms and favors its large-scale outdoor mass production. Annual 
production of Spirulina worldwide was 2,000 $\mathrm{t}$ in the year 2000 (Hu, 2004). Mixotrophic mass production presents higher yields (Chen et al., 1997). Today, Arthrospira sp. mass production is occurring all over the world, with most of the production facilities being located in the Asia-Pacific region (Lee, 1997).

Dunaliella sp. is the most halotolerant eukaryotic photosynthetic organism, known for its remarkable ability to adapt to different salt concentrations from as low as $0.1 \mathrm{M}$ to salt saturation (4 M) (Ben-Amotz, 2004). It is the most suitable organism for outdoor mass cultivation in open ponds. The autotrophic mass production mode is adapted for large-scale Dunaliella production in media containing inorganic nutrients with carbon dioxide as the sole carbon source (BenAmotz, 2004).

Attempts at the heterotrophic production of Dunaliella have not, however, been successful as yet. This organism is one of the best natural sources of $\beta$-carotene, and a modern intensive plant of $50,000 \mathrm{~m}^{2}$ can produce $3,650 \mathrm{~kg}$ per year. The optimal growth medium for Dunaliella should ideally contain around $1.5 \mathrm{M} \mathrm{NaCl}$, more than $0.4 \mathrm{M} \mathrm{MgSO}_{4}$, and $0.1 \mathrm{M} \mathrm{CaCl}_{2}$ under $\mathrm{pH}$ control (Ben-Amotz, 2004).

Aphanizomenon sp., a fresh water cyanobacterium was first exploited in the1980s after the first harvest of natural bloom in Klamath Lake (Oregon, USA) (Carmichael et al., 2000). Two thousand tons of this organism were harvested in 1998 from the lake. Natural harvesting presents some obstacles such as the harmful chemical composition of the harvested biomass and contamination by other species or strains that produce neurotoxins or other undesirable substances. The development of large-scale production photobioreactors for Aphanimezonon is therefore of the utmost importance.

Nostoc sp. can develop under various climatic conditions including the Polar Regions, hot springs and deserts. The optimum temperature for the growth of this cyanobacterium is between $15^{\circ} \mathrm{C}$ and $25^{\circ} \mathrm{C}$ (Cui, 1983). It shows a great adaptability to a wide range of temperatures. Nostoc was consumed by the Chinese in order to survive during times of famine 2,000 years ago (Danxiang et al., 2004). However, the cultivation of this organism has never progressed beyond the experimental level.

In addition to its relatively high protein content, Scenedesmus sp. is mostly cultivated for biofuel production because of its high lipid content (31.7\%) and high biomass productivity compared to other microalgae sources (Xia et al., 2014). A recent study carried out in China by Xia et al. (2014) showed that Scenedesmus obtusus presented the highest biomass productivity $\left(20.2 \mathrm{~g} \cdot \mathrm{m}^{-1} \cdot \mathrm{d}^{-1}\right)$ compared to the other tested species. Microalgae species such as Scenedesmus sp. and Chlorella sp. are currently mostly being produced for biofuel synthesis, and the by-product obtained after lipid extraction can be readily valorized for its high protein content.

In another recent study on Scenedesmus mass production by Abomohra et al. (2014), Scenedesmus sp. was cultivated in a semi-continuous culture for 3 months in polyethylene transparent bags. A maximum productivity of $0.14 \mathrm{~g} \cdot \mathrm{l}^{-1} \cdot \mathrm{d}^{-1}$ was obtained from this experimental mass production. As part of this study, harvesting methods were also investigated using different flocculants, and a maximum flocculation of $82 \%$ was achieved using $250 \mathrm{mg} \cdot \mathrm{l}^{-1}$ of $\mathrm{NaOH}$ for $2 \mathrm{~h}$.

Investigations into the feasibility of growing Porphyridium biomass outdoors were carried out as early as 1985 by Vonshak et al. in a laboratory study. It was found that, although the optimum temperature for the growth of Porphyridium is known to be $25^{\circ} \mathrm{C}$, no damage to photosynthetic activity was detected after exposure of the organism to higher temperatures, up to $35^{\circ} \mathrm{C}$. In addition, high $\mathrm{O}_{2}$ evolution activity was observed at relatively high cell concentrations, and no inhibition of $\mathrm{O}_{2}$ evolution was detected at high light intensity. A production rate of up to $22 \mathrm{~g} \cdot \mathrm{m}^{-2} \cdot \mathrm{d}^{-1}$ (dry weight) was obtained for several weeks during outdoor cultivation.

In a study on the strain Porphyridium purpureum by Velea et al. (2011), the growth rate was optimized using a two-variable experimental design (light and sodium bicarbonate feeding), by amending the ASW (artificial sea water) nutrient medium with additional amounts of $\mathrm{NaHCO}_{3}$. The study showed that increased light intensity and $\mathrm{NaHCO}_{3}$ in ASW medium led to substantial increases in biomass production, as well as in exopolysaccharide yields. Exopolysaccharides and phycobiliproteins are often the targeted substances in Porphyridium sp. mass cultivation.

The biotechnology involved in Porphyridium outdoor production was developed as early as the late 1970s by Gudin et al. ${ }^{2}$ (1991), cited by Arad et al. (2004). Indoor bioreactors for the mass production of Porphyridium sp. showed that a custom-built flat-sided photobioreactor with a higher exposed surface area to volume ratio provided the best production system (Iqbal et al., 1993).

Moreno et al. (2003) investigated outdoor mass cultivation of the nitrogen-fixing marine cyanobacterium Anabaena sp. ATCC 33047. The authors found that, in open ponds operated under a semi-continuous biomass regime, productivity values achieved ranged from $9 \mathrm{~g} \cdot \mathrm{m}^{-2} \cdot \mathrm{d}^{-1}$ (dry weight), in winter, to over $20 \mathrm{~g} \cdot \mathrm{m}^{-2} \cdot \mathrm{d}^{-1}$, in summer, provided that key operation parameters, including cell density,

\footnotetext{
${ }^{2}$ Gudin C. \& Chaumont D., 1991. Cell fragility - the key problem of microalgae mass production in closed photobioreactors. Bioresour. Technol., 38, 145-151.
} 
were optimized. Under these conditions, the harvested biomass was rich in high-value phycobiliproteins, namely allophycocyanin and phycocyanin, for which open cultures of marine Anabaena represent a most interesting production system.

An assessment of the $\mathrm{CO}_{2}$ fixation and biomass productivity of Anabaena sp. ATCC 33047 was carried out by Clares et al. (2014). In this study, the highest values achieved for $\mathrm{CO}_{2}$ fixation rate and biomass productivity were 1 and $0.6 \mathrm{~g} \cdot \mathrm{l}^{-1} \cdot \mathrm{d}^{-1}$, respectively.

Gonzàles López et al. (2009) investigated the carbon dioxide removal capacity of Anabaena sp. Results showed a maximum $\mathrm{CO}_{2}$ fixation rate of $1.45 \mathrm{~g} \cdot \mathrm{l}^{-1} \cdot \mathrm{d}^{-1}$ $\mathrm{CO}_{2}$, which could be increased to up to $3.0 \mathrm{~g} \cdot \mathrm{l}^{-1} \cdot \mathrm{d}^{-1} \mathrm{CO}_{2}$ outdoors for the species investigated.

Tetraselmis sp. is also a halotolerant form of microalgae that can be used either as food or feed, or for biofuel synthesis. A number of studies have been carried out to assess and improve the mass production conditions for this organism. The ability of Tetraselmis sp. to thrive in high salt concentrations is sustained through variable levels of starch production as a result of metabolic stress linked to new growing media conditions. A study carried out by Yao et al. (2013) on Tetraselmis subcordiformis showed that decreased salinity combined with nitrogen-generated moderate stress facilitated starch accumulation. The authors concluded that salinity manipulation can be effectively applied for enhanced starch production in marine microalgae.

Results of a recent pilot-scale mass production study by Fon Sing et al. (2014) showed that a peak productivity of $37.5 \pm 3.1 \mathrm{~g} \cdot \mathrm{m}^{-2} \cdot \mathrm{d}^{-1}$ ash free dry weight (AFDW) was reached in a recycled medium upon transition from $14 \%$ to $7 \% \mathrm{NaCl}$. The combination of high biomass-yielding mixotrophic growth under high salinity has proved to be a successful sustainable cultivation strategy.

\section{PROTEIN CONTENT OF SOME MICROALGAE BIOMASS}

Most microalgae exhibit a high protein content (Table 1), with the largest values being reported for

Table 1. Protein content (\% dry weight basis), class, and kingdom of different microalgae - Teneur en protéines (\% en masse de matière sèche), classe et règne de différentes microalgues.

\begin{tabular}{|c|c|c|c|c|}
\hline Alga & $\begin{array}{l}\text { Protein } \\
\text { content }(\%)\end{array}$ & Class & Domain (kingdom) & Reference \\
\hline Anabaena cylindrica & $43-56$ & Cyanophycea & Procaryota (Eubacteria) & Becker, 2007 \\
\hline Aphanizomenon flos-aquae & 62 & Cyanophycea & Procaryota (Eubacteria) & Becker, 2007 \\
\hline Arthrospira maxima & $56-77$ & Cyanophyceae & Procaryota (Bacteria) & Paoletti et al., 1980 \\
\hline Chlorella ellipsoidea & 42.2 & Trebouxiophyceae & Eukaryota (Plantae) & Servaites et al., 2012 \\
\hline Chlorella ovalis & 10.97 & Trebouxiophyceae & Eukaryota (Plantae) & Slocombe et al., 2013 \\
\hline Chlorella pyrenoidosa & 57 & Trebouxiophyceae & Eukaryota (Plantae) & Becker, 2007 \\
\hline Chlorella spaerckii & 6.87 & Trebouxiophyceae & Eukaryota (Plantae) & Slocombe et al., 2013 \\
\hline Chlorella vulgaris & $\begin{array}{l}51-58 \\
53.3\end{array}$ & Trebouxiophyceae & Eukaryota (Plantae) & $\begin{array}{l}\text { Becker, } 2007 \\
\text { Sean et al., } 2015\end{array}$ \\
\hline Dunaliella primolecta & 12.26 & Chlorophyceae & Eukaryota (Plantae) & Slocombe et al., 2013 \\
\hline Dunaliella salina & 57 & Chlorophyceae & Eukaryota (Plantae) & Becker, 2007 \\
\hline Dunaliella tertiolecta & 11.4 & Chlorophyceae & Eukaryota (Plantae) & Barbarino et al., 2005 \\
\hline Porphyridium aerugeneum & 31.6 & Porphyridiophycea & Eukaryota (Plantae) & Sean et al., 2015 \\
\hline Porphyridium cruentum & $\begin{array}{l}35 \\
28-39\end{array}$ & Porphyridiophycea & Eukaryota (Plantae) & $\begin{array}{l}\text { Gonzàles López et al., } 2010 \\
\text { Becker, } 2007\end{array}$ \\
\hline Scenedesmus almeriensis & 41.8 & Chlorophyceae & Eukaryota (Plantae) & Romero et al., 2012 \\
\hline Scenedesmus obliquus & $\begin{array}{l}48 \\
50-55\end{array}$ & Chlorophyceae & Eukaryota (Plantae) & $\begin{array}{l}\text { Gonzàles López et al., } 2010 \\
\text { Becker, } 2007\end{array}$ \\
\hline Spirulina platensis & $\begin{array}{l}60-71 \\
55.8\end{array}$ & Cyanophyceae & Procaryota (Bacteria) & $\begin{array}{l}\text { Paoletti et al., } 1980 \\
\text { Sean et al., } 2015\end{array}$ \\
\hline Tetraselmis & 36 & Prasinophyceae & Eukaryota (Plantae) & Schwenzfeier et al., 2011 \\
\hline Tetraselmis chuii & $\begin{array}{l}31 \\
46.5\end{array}$ & $\begin{array}{l}\text { Prasinophyceae } \\
\text { Prasinophyceae }\end{array}$ & $\begin{array}{l}\text { Eukaryota (Plantae) } \\
\text { Eukaryota (Plantae) }\end{array}$ & $\begin{array}{l}\text { Brown, } 1991 \\
\text { Sean et al., } 2015\end{array}$ \\
\hline
\end{tabular}


the Spirulina (Arthrospira) species (55.8 to $77 \%$ ). The variability within values for protein content reported by different authors is remarkable for some species such as Dunaliella sp. This can be seen, for example, in a comparison of the values found for the species Dunaliella tertiolecta (11.4\%) (Barbarino et al., 2005) and for Dunaliella salina (57\%) (Becker, 2007) (Table 1). Reported values may also depend on the analytical methods used in a study and on the origin of the analyzed biomass (growth medium, harvesting period, production method, etc.).

Spirulina sp. (Arthrospira sp.) is a genus of freefloating filamentous cyanobacteria characterized by bicylindrical, multicellular trichomes in an open lefthand helix. It is a ubiquitous microalga, capable of adaptation to very different habitats, colonizing certain environments in which life proves very difficult or impossible for other microorganisms (Orio, 1983).

A French phycologist Dangeard (1940) reported that a substance called Dihe in the local language (Kanembu), was eaten by the native population, and was obtained by sun drying mats of microscopic algae harvested from the surface of small lakes or ponds around Lake Chad (Orio, 1983). The alga was identified as Spirulina (Arthrospira) platensis. At the same time, another Spirulina sp., S. maxima, was discovered to be growing abundantly in Lake Texcoco, near Mexico City (Orio, 1983). Findings in the literature have clearly revealed the historical use of Spirulina maxima and Spirulina platensis species as human food.

Spirulina proteins contain a large quantity of phycobiliprotein (about 20\% of the total protein content), including phycocyanins, known for their attractive blue color and tremendous health effects on the human organism, as demonstrated by a large volume of literature (Romay et al., 1998; Gonzàlez et al., 1999; Bhat et al., 2001; Madhava et al., 2003). Spirulina appears to be able to yield a high protein content, with up to $77 \%$ for Arthrospira maxima (Paoletti et al., 1980) (Table 1) on a dry weight basis.

Aphanizomenon sp. are filamentous free-floating solitary algae. In a few species, these algae are joined into fascicle-like, microscopic or macroscopic (up to $2 \mathrm{~cm}$ long) colonies with trichomes oriented in parallel. They are prokaryotic cyanobacteria of the Nostocacea family. In comparison with Arthrospira, Aphanizomenon flos-aquae has only recently been used for human consumption. The exploitation of A.flos-aquae started in the early 1980s (Carmichael et al., 2000). This organism is capable of yielding a protein content on a dry matter basis of 62\% (Table 1) (Becker, 2007). Some studies have revealed the presence of hepatotoxic microcystins in foods supplemented with A. flos-aquae at the level of 0.1-4.72 $\mu \mathrm{g} \cdot \mathrm{g}^{-1}$ (Saker et al., 2005), but their source remains unknown. These toxic substances may have resulted from exogenous contamination.
Anabaena sp. is among the filamentous microalgae species also known as cyanobacteria. The species has a high ability to fix nitrogen and to remove $\mathrm{CO}_{2}$ from polluted water (González López et al., 2010). Despite their relatively high protein content (43-56\%) (Becker, 2007), these organisms represent one of the four genera of cyanobacteria biomass that have been shown to contain neurotoxins (Anabaena sp., Aphanizomenon sp., Planktothrixagardhii and Microcystis sp.) (PawlikSkoronska et al., 2013).

Chlorella sp. is a green microalga of the phylum chlorophyta. It has a spherical shape of about 2 to $10 \mu \mathrm{m}$ in diameter (Scheffler, 2007). Its protein content shows a wide range among the strains of the species, starting from as low as $6.87 \%$ for the species Chlorella spaerckii (Slocombe et al., 2013) to as high as $58 \%$ for Chlorella vulgaris (Becker, 2007) (Table 1). Chlorella spaerckii and Chlorella ovalis (10.87\%) (Slocombe et al., 2013) appear to be poor sources of protein, and the mass production of these strains would therefore be better directed towards other uses, such as lipid extraction for biofuel synthesis. However, the proteins that are produced could be exploited as by-products after lipid extraction.

Scenedesmus sp. is also a eukaryotic microalga, which features among the most common freshwater genera. Scenedesmus almeriens is a novel strain of Scenedesmus sp., which presents many advantages such as a high growth rate, and tolerance to both high temperatures and high copper concentrations. In addition to its high protein content, Scenedesmus sp. is also an important source of carotenoids, especially lutein, which is known for its protective effect against photochemical damage of the macular region of the eye (Landrum, 1997). The protein content of Scenedesmus sp. has been found to be in the range of 30-50\%, depending on the cell disruption pretreatment method applied (González López et al., 2010). A protein content of $41.8 \%$ for the strain Scenedesmus almeriensis was reported by Romero et al. (2012).

In his study, Becker (2007) reported a protein content for Scenedesmus obliquus of between 50 and 55\%, while González López et al. (2010) reported 48\%. As for most microalgae, the protein content of Scenedesmus has been shown to vary widely (30-55\%), depending on the cell disruption pre-treatment method applied, the strain of the species and probably the nature of the growth medium, among other factors.

Tetraselmis sp. is a genus of green unicellular flagellated eukaryotic microalgae (usually $10 \mu \mathrm{m}$ long $\mathbf{X}$ $14 \mu \mathrm{m}$ wide). Most strains possess 8 flagella, while a few possess 16 flagella.

Tetraselmis is characterized by its high lipid content (22\%) but the protein level is also relatively high (31$36 \%$ ) compared to some high protein sources, such as soya bean (37\%) and milk (26\%) (Brown, 1991; Becker, 1994; Schwenzfeier et al., 2011). 
Porphyridium sp. is a eukaryotic red microalgal species belonging to the Porphyridiaceae family and the Porphyridiophyceae class. It has a high carbohydrate content, and is especially known for the beneficial health effects of its sulphated polysaccharides (Patel et al., 2013). The protein content of Porphyridium cruentum has been shown to vary from approximately $30 \%$ to $35 \%$, depending on the cell disruption pretreatment applied (González López et al., 2010). A recent study by Sean et al. (2015), on the chemical composition of some microalgae species, revealed the crude protein content of the species Porphyridium aerugeneum to be $31.6 \%$ on a dry weight basis.

The halotolerant biflagellated alga Dunaliella sp. is known for its orange-red pigment $\beta$-carotene, a precursor of vitamin A. Dunaliella proteins are reported to play a role in fighting against the transient intracellular salt fluctuations during hyperosmotic or hypoosmotic shocks (Chen et al., 2015). Results from a study by Tavallaie et al. (2015) on the protein production of Dunaliella salina showed that protein production and pigmentation correlated well with the growth rate of the strain. Dunaliella sp. is one of the few microalgae that are produced commercially on a relatively large scale (Ben-Amotz, 2004). Becker (2007) reported a protein content of $57 \%$ for the species $D$. salina on a dry weight basis. Lower levels of protein content have been reported for the species Dunaliella primolecta (12.26\%) (Slocombe et al., 2013) and Dunaliella tertiolecta (11.4\%) (Barbarino et al., 2005).

\section{NUTRITIONAL AND FUNCTIONAL PROPERTIES OF MICROALGAE PROTEIN}

Parameters measured for protein quality include the protein efficiency ratio (PER) expressed as the mass gain per unit of consumed protein, tested on animals in short-term trials. Other parameters that have been measured for the nutritional quality of a protein are the determination of its biological value (BV), giving the proportion of absorbed protein, the protein digestibility coefficient (DC), and the net protein utilization (NPU) equivalent to a calculation of (BV) X (DC) (Becker, 2007) (Table 2). The method chosen for drying the microalgae biomass seems to have an impact on these parameters. Chlorella sp. DD, Spirulina sp. SD, and Scenedesmus obliquus DD have shown the highest values among the tested microalgae biomass, values that are not far from those of the referenced sources casein and egg. To some extent, these microalgae may be able to readily replace the conventional protein sources in a diet.

One of the quality criteria for a protein is its amino acid composition, specifically the essential amino acids.
Table 2. Comparative data on biological value (BV), digestibility coefficient (DC), net protein utilization (NPU), and protein efficiency ratio (PER), of differently processed algae (Becker, 2007 based on Becker, 2004; Richmond, 2004) - Données comparatives sur la valeur biologique $(V B)$, le coefficient d'utilisation digestive (CUD), l'utilisation nette des protéines (UNP) et le rapport d'efficacité protéique (REP) des algues transformées de différentes manières (Becker, 2007 basé sur Becker, 2004; Richmond, 2004).

\begin{tabular}{|c|c|c|c|c|c|}
\hline & Processing & BV & DC & NPU & PER \\
\hline Casein & & 87.8 & 95.1 & 83.4 & 2.50 \\
\hline Egg & & 94.7 & 94.2 & 89.1 & - \\
\hline \multicolumn{6}{|l|}{ Alga } \\
\hline $\begin{array}{l}\text { Scenedesmus } \\
\text { obliquus }\end{array}$ & DD & 75.0 & 88.0 & 67.3 & 1.99 \\
\hline $\begin{array}{l}\text { Scenedesmus } \\
\text { obliquus }\end{array}$ & DS & 72.1 & 72.5 & 52.0 & 1.14 \\
\hline $\begin{array}{l}\text { Scenedesmus } \\
\text { obliquus }\end{array}$ & Cooked -SD & 71.9 & 77.1 & 55.5 & 1.20 \\
\hline Chlorella sp. & $\mathrm{AD}$ & 52.9 & 59.4 & 31.4 & 0.84 \\
\hline Chlorella sp. & DD & 76.0 & 88.0 & 68.0 & 2.00 \\
\hline Spirulina sp. & SD & 77.6 & 83.9 & 65.0 & 1.78 \\
\hline Spirulina sp. & $\mathrm{DD}$ & 68.0 & 75.5 & 52.7 & 2.10 \\
\hline
\end{tabular}

AD: air dried - séché à l'air; DD: drum dried - séché sur tambour; SD: sun dried - séché sous le soleil.

There is evidence in the literature showing that, in this regard, algae protein can readily compare with proteins derived from conventional sources. Values for amino acid content (Table 3), reported by Kent et al. (2015), compare well with those presented by Christaki et al. (2011). The slight differences shown may be due to the differences between the tested microalgae species or the origin of the analyzed biomass. All essential amino acid levels reported for the various microalgae species also compare well to those of the conventional sources of protein. The essential amino acid cysteine appears to have been the same limiting amino acid for egg and for most of the analyzed microalgae species. Microalgae as a protein source can readily substitute for egg or other animal protein. Their amino acid profile is far superior to that of soybean and to that of other plant sources when considering the essential amino acid content.

Some microalgae proteins exhibit good functional properties and are readily integrated into food formulations for health management. Phycobiliproteins found in cyanobacteria, such as Spirulina sp., Anabaena sp., and Oscillatoria sp., are colored proteins, recognized for their large number of health applications, and they have been intensively 


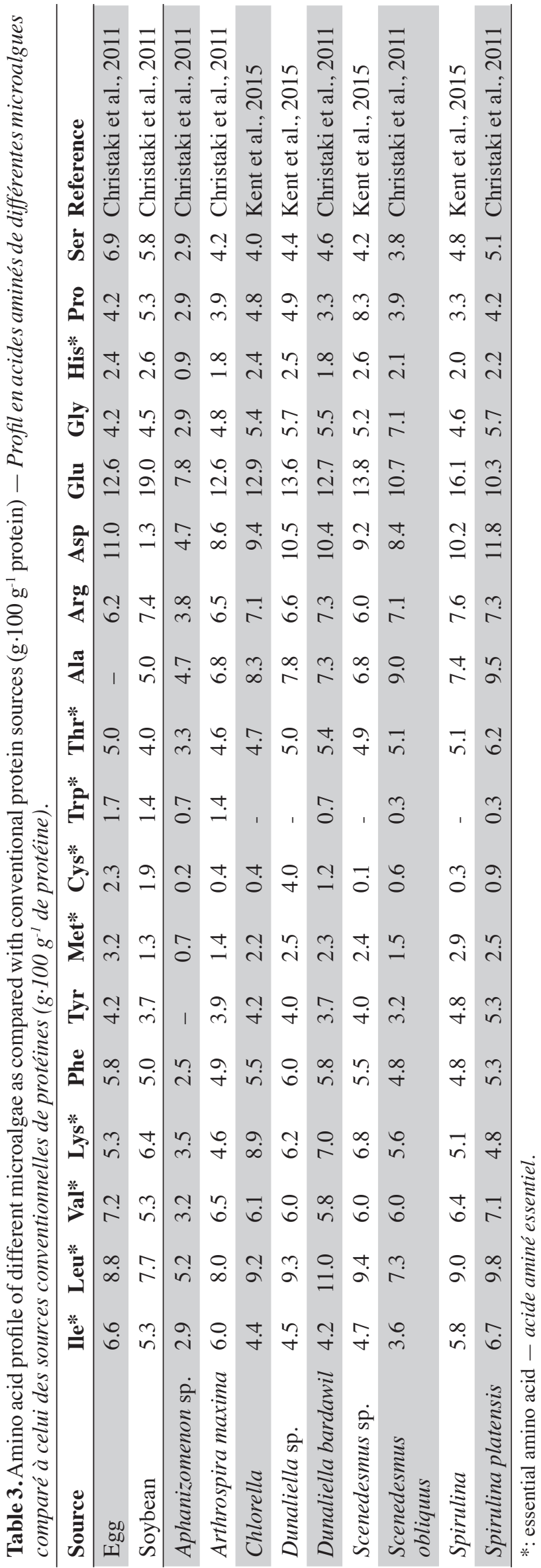

investigated for this purpose. These proteins include allophycocyanin, phycocyanin, and phycoerythrin.

A molecule of phycocyanin is made up of two subunits linked together: a protein unit and a bilin chromophore unit (Figure 1). The chemical structure of the bilin chromophores in phycocyanin is close to that of bilirubin, a heme breakdown product. Bilirubin acts as an antioxidant and cytoprotector for tissues such as myocardium and nervous tissue, by scavenging oxygen free radicals (Temme et al., 2001).

\section{PHYSICOCHEMICAL AND TECHNOFUNCTIONAL PROPERTIES OF ALGAL PROTEINS}

The term "technofunctional" has been suggested to describe the properties of proteins and other nutrients that, in addition to their nutritional function, are capable of playing other roles in food formulation. The technofunctional properties of proteins include all the physicochemical properties that would affect their technological applications during processing, handling and consumer use. These properties are strongly involved in enhancing the organoleptic characteristics of processed food, including texture, viscosity, palatability, mouth feel, etc. The technofunctional properties of food proteins involve two molecular aspects (Damodaran, 1989), i.e. protein-surface related properties (solubility, wettability, dispersibility, foaming, emulsification, flavor and fat binding) and hydrodynamic properties (viscosity, thickening, gelation, texturization).

Although proteins are the main focus of interest with respect to substances obtained from microalgae, their characterization remains incomplete. Only a few scientific publications are available on the technofunctional properties of algal protein, mainly relating to the soluble protein fractions of Spirulina sp. and Tetraselmis sp. Examples of such properties are highlighted below.

Chronakis et al. (2000) found that the soluble protein fraction of Spirulina platensis had remarkable properties in reducing the surface tension.

More recently, Mahajan et al. (2010) compared native and chemically modified Spirulina proteins for their functional properties. Results showed that Spirulina protein solubility in water decreased considerably when treated with succinic anhydride, acetic anhydride and formaldehyde. Foam stability was found to be higher with methylation and acetylation. Maximum viscosity was obtained with the succinic anhydride modified protein fraction followed by acetylation.

The emulsifying and foaming properties of Tetraselmis soluble protein isolate were investigated 
a

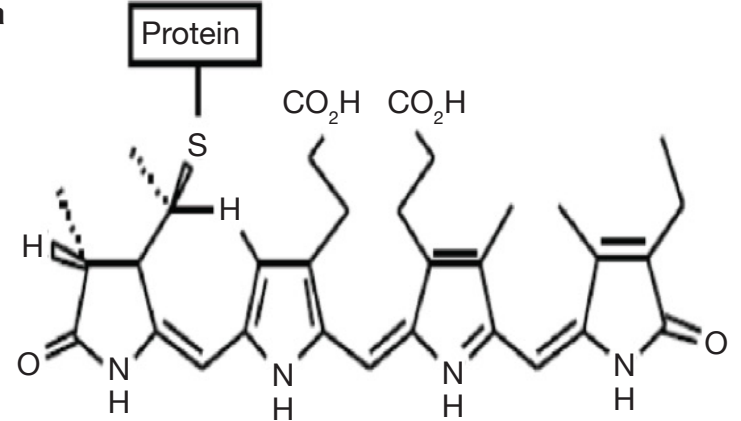

b

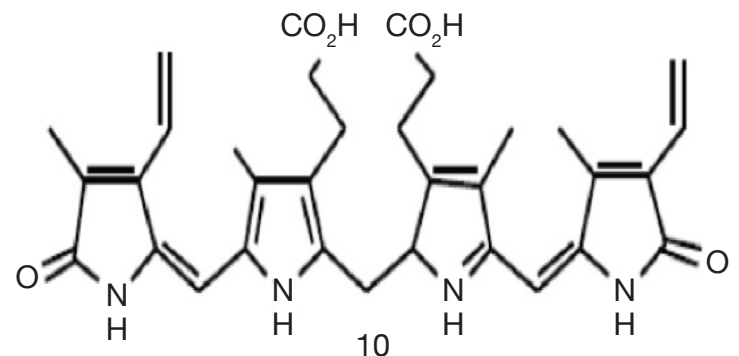

Figure 1. Chemical structure of phycocyanibilin chromophore (open-chain tetrapyrrol) (a) and bilirubin (b) - Structure chimique du chromophore de phycocyanobiline (chaine ouverte tetrapyrrole) (a) et de bilirubine (b) (Romay et al., 2003).

by Schwenzfeier et al. (2011; 2013). This algae isolate appeared to be a mixture of mainly proteins and polysaccharides. Since Tetraselmis allows the formation of stable emulsions at low protein concentrations, it can be considered as an efficient natural alternative to existing protein-polysaccharide complexes such as gum arabic. Moreover, the overall foam stability of the algae protein-rich fraction was found to be superior to that of whey protein isolate and egg white albumin in the $\mathrm{pH}$ range from 5 to 7.

\section{CONCLUSIONS}

Microalgae are quantitatively and qualitatively good protein sources. Their potential use in human nutrition has not yet been fully realized, and is currently generally limited to functional food ingredients. Some species, such as Chlorella sp., Aphanomezinon sp., Nostoc sp., and Spirulina sp., have an historical use in human nutrition, but they are still more or less confined to their natural areas of production, and their industrial production remains limited. Mass production of microalgae needs to be encouraged by public authorities in order to help overcome food shortages for the growing global population. However, the complete toxicological, microbiological and biochemical status of algal products would need to be determined before their full integration as basic ingredients into processed foods, whether for functional or solely nutritional purposes.

\section{Acknowledgements}

Financial support for $\mathrm{Mr}$ A. Barka was provided by CONFOFOR-TCHAD and the Laboratory of Science des Aliments et Formulation, Gembloux Agro-Bio Tech. The authors are grateful to Mrs Lynn Doran for her contribution.

\section{Bibliography}

Abomohra Abd El-Fatah, El-Sheekh M. \& Hanelt D., 2014. Pilot cultivation of the chlorophyte microalga Scenedesmus obliquus as a promising feedstock for biofuel. Biomass Bioenergy, 64, 237-244

Arad S. \& Richmond A., 2004. Industrial production of microalgal cell-mass and secondary products - species of high potential: Porphyridium sp. In: Richmond A. Handbook of microalgal culture. Biotechnology and applied phycology. Oxford, UK: Blackwell, 289297.

Barbarino E. \& Lourenço S.O., 2005. An evaluation of methods for extraction and quantification of protein from marine macro- and microalgae. J. Appl. Phycol., 17, 447-460.

Becker E.W., 1994. Microalgae: biotechnology and microbiology. Cambridge, UK: Cambridge University Press.

Becker E.W., 2004. Microalgae in human and animal nutrition. In: Richmond A. Handbook of microalgal culture. Biotechnology and applied phycology. Oxford, UK: Blackwell, 312-351.

Becker E.W., 2007. Micro-algae as a source of protein. Biotechnol. Adv., 25, 207-210.

Ben-Amotz A., 2004. Industrial production of microalgal cell-mass and secondary products. Major industrial species: Dunaliella. In: Richmond A. Handbook of microalgal culture. Biotechnology and applied phycology. Oxford, UK: Blackwell, 273-280.

Bhat V.B. \& Madyastha K.M., 2001. Scavenging of peroxynitrite by phycocyanin and phycocyanobilin from Spirulina platensis: protection against oxidative damage to DNA. Biochem. Biophys. Res. Commun., 285, 262266.

Brown M.R., 1991. The amino-acid and sugar composition of 16 species of microalgae used in mariculutre. J. Exp. Mar. Biol. Ecol., 145, 79-99.

Carmichael W.W., Drapeau C. \& Anserson D.M., 2000. Harvesting of Aphanizomenon flos-aquae Ralfs ex Born. 
\& Flah. var. flos-aquae (cyanobacteria) from Klamath lake for human dietary use. J. Appl. Phycol., 12, 585595.

Chen F. \& Zhang Y., 1997. High cell density mixotrophic culture of Spirulina platensis on glucose for phycocyanin production using a fed-batch system. Enzyme Microb. Technol., 20, 221-224.

Chen X.-J. et al., 2015. Dunaliella salina Hsp90 is halotolerant. Int. J. Biol. Macromol., 75, 418-425.

Christaki E., Florou-Paneri P. \& Bonos E., 2011. Microalgae: a novel ingredient in nutrition. Int. J. Food Sci. Nutr., 62(8), 794-799.

Christaki E. et al., 2012. Effect of dietary Spirulina platensis on milk fatty acid profile of dairy cows. Asian J. Anim. Vet. Adv., 7, 597-604.

Chronakis I.S., Galatanu A.N., Nylander T. \& Lindman B., 2000. The behaviour of protein preparations from bluegreen algae (Spirulina platensis strain Pacifica) at the air/water interface. Colloids Surf., A, 173, 181-192.

Clares M.E., Moreno J., Guerrero M.G. \& GarcíaGonzález M., 2014. Assessment of the $\mathrm{CO}_{2}$ fixation capacity of Anabaena sp. ATCC 33047 outdoor cultures in vertical flat-panel reactors. J. Biotechnol., 187, 5155.

Cui Z., 1983. Culture trial of Facai in soil-soaked solution. Sci. Technol. Lett. Inner Mongolia, 4, 10-38.

Dangeard P., 1940. Sur une algue bleue alimentaire pour l'homme: Arthrospira platensis (Nordst.) Gomont. Actes Soc. Linn. Bordeaux Extr. P.V., 91, 39-41.

Danxiang H., Yonghong B. \& Zhengyu H., 2004. Industrial production of microalgal cell-mass and secondary products - major industrial species: Nostoc. In: Richmond A. Handbook of microalgal culture. Biotechnology and applied phycology. Oxford, UK: Blackwell, 304-331.

Fon Sing S., Isdepsky A., Borowitzka M.A. \& Lewis D.M., 2014. Pilot-scale continuous recycling of growth medium for the mass culture of a halotolerant Tetraselmis $\mathrm{sp}$. in raceway ponds under increasing salinity: a novel protocol for commercial microalgal biomass production. Bioresour. Technol., 161, 47-54.

González López C.V. et al., 2009. Utilization of the cyanobacteria Anabaena sp. ATCC 33047 in $\mathrm{CO}_{2}$ removal processes. Bioresour. Technol., 100, 5904-5910.

González López C.V. et al., 2010. Protein measurements of microalgal and cyanobacterial biomass. Bioresour. Technol., 101, 7587-7591.

Gonzàlez R. et al., 1999. Anti-inflammatory activity of phycocyanin extract in acetic acid-induced colitis in rats. Pharmacol. Res., 39(1), 55-59.

Gouveia L. et al., 2008. Microalgae in novel food products. In: Papadopoulos K.N., ed. Food chemistry research developments. Hauppauge, NY, USA: Nova Science Publishers, Inc, 37.

$\mathrm{Hu}$ Q., 2004. Industrial production of microalgal cellmass and secondary products major industrial species:
Arthrospira (Spirulina) platensis. In: Richmond A. Handbook of microalgal culture. Biotechnology and applied phycology. Oxford, UK: Blackwell, 265272.

Iqbal M., Zafar S.I., Stepan-Sarkissian G. \& Fowler M.W., 1993. Indoor mass cultivation of red alga Porphyridium cruentum in different types of bioreactors: effect of scale-up and vessel shape. J. Ferment. Bioeng., 75(3), 76-78.

Iwamoto H., 2004. Industrial production of microalgal cellmass and secondary products - major industrial species: Chlorella. In: Richmond A. Handbook of microalgal culture. Biotechnology and applied phycology. Oxford, UK: Blackwell, 255-263.

Kent M., Welladsen M.H., Mangott A. \& Li Y., 2015. Nutritional evaluation of Australian microalgae as potential human health supplements. PLoS One, 10(2), e0118985.

Landrum J.T., Bone R.A. \& Kilburn M.D., 1997. The macular pigment: a possible role in protection from age-related macular degeneration. Adv. Pharmacol., 38, 537-556.

Lee Y.-K., 1997. Commercial production of microalgae in the Asia-Pacific rim. J. Appl. Phycol., 9, 403-411.

Madhava Reddy C. et al., 2003. C-Phycocyanin, a selective cyclooxygenase-2 inhibitor, induces apoptosis in lipopolysaccharide-stimulated RAW 264.7 macrophages. Biochem. Biophys. Res. Commun., 304(2), 385-392.

Mahajan A. \& Ahluwalia A.S., 2010. Effect of processing on functional properties of Spirulina protein preparations. Afr. J. Microbiol. Res., 4(1), 55-60.

Margulis L., 1981. Symbiosis in cell evolution. New York, NY, USA: W.H. Freeman.

Moorhead K. \& Capelli B., 2011. Spirulina nature's superfood. $3^{\text {rd }}$ ed. Kailua-Kona, Hawaii: Cyanotech Corporation.

Moreno J. et al., 2003. Outdoor cultivation of a nitrogenfixing marine cyanobacterium, Anabaena sp. ATCC 33047. Biomol. Eng., 20(4-6), 191-197.

Orio Ciferri, 1983. Spirulina, the edible microorganism. Microbiol. Rev., 47(4), 551-578.

Paoletti C., Vincenzini M., Bocci F. \& Materassi R., 1980. Composizione biochimica generale delle biomasse di Spirulina platensis e S. Maxima. In: Materassi R., ed. Prospettive della coltura di Spirulina in Italia. Roma: Consiglio Nazionale delle Ricerche, 111-125.

Patel A.K. et al., 2013. Separation and fractionation of exopolysaccharides from Porphyridium cruentum. Bioresour. Technol., 145, 345-350.

Pawlik-Skowronska B., Kalinowska R. \& Skowronski T., 2013. Cyanotoxin diversity and food web bioaccumulation in a reservoir with decreasing phosphorus concentrations and perennial cyanobacterial blooms. Harmful Algae, 28, 118-125.

Praveenkumar R. et al., 2014. Improved biomass and lipid production in a mixotrophic culture of Chlorella sp. 
KR-1 with addition of coal-fired flue-gas. Bioresour. Technol., 171, 500-505.

Richmond A., 2004. Handbook of microalgal culture. Biotechnology and applied phycology. Oxford, UK: Blackwell.

Romay Ch. et al., 1998. Antioxidant and anti-inflammatory properties of C-phycocyanin from blue-green algae. Inflammation Res., 47, 36-41.

Romay Ch. et al., 2003. Phycocyanin: a biliprotein with antioxidant, anti-inflammatory and neuroprotective effects. Curr. Protein Pept. Sci., 4, 207-216.

Romero García J.M., Acién Fernández F.G. \& Fernández Sevilla J.M., 2012. Development of a process for the production of L-amino acids concentrates from microalgae by enzymatic hydrolysis. Bioresour. Technol., 112, 164-170.

Saker M.L. et al., 2005. Detection of microcystin synthetase genes in health food supplements containing the freshwater cyanobacterium Aphanizomenon flos-aquae. Toxicon, 46(5), 555-562.

Scheffler J., 2007. Underwater habitats. Illumin, 9(4).

Schwenzfeier A., Helbig A., Wierenga P.A. \& Gruppen H., 2011. Isolation and characterization of soluble protein from the green microalgae Tetraselmis sp. Bioresour. Technol., 102(19), 9121-9127.

Schwenzfeier A., Wierenga P.A. \& Gruppen H., 2013. Emulsion properties of algae soluble protein isolate from Tetraselmis sp. Food Hydrocolloids, 30(1), 258-263.

Servaites J.C., Faet J.L. \& Sidhu S.S., 2012. A dye binding method for measurement of total protein in microalgae. Anal. Chem., 421, 75-80.

Simpore J. et al., 2006. Nutrition rehabilitation of undernourished children utilizing Spiruline and Misola. Nutr. J., 5(3), doi:10.1186/1475-2891-5-3
Slocombe S.P. et al., 2013. A rapid and general method for measurement of protein in microalgal biomass. Bioresour. Technol., 129, 51-57.

Tavallaie S. et al., 2015. Comparative studies of $\beta$-carotene and protein production from Dunaliella salina isolated from Lake Hoze-soltan, Iran. J. Aquat. Food Prod. Technol., 24, 79-90.

Temme E.H.M., Zhang J., Schouten E.G. \& Kesteloot H., 2001. Serum bilirubin and 10-year mortality risk in a Belgian population. Cancer Causes Control, 12, 887894.

Tibbetts S.M., Milley J.E. \& Lall S.P., 2015. Chemical composition and nutritional properties of freshwater and marine microalgal biomass cultured in photobioreactors. J. Appl. Phycol., 27, 1109-1119.

Velea S., Ilie L. \& Filipescu L., 2011. Optimization of Porphyridium purpureum culture growth using two variables experimental design: light and sodium bicarbonate. U.P.B. Sci. Bull. Ser. B, 73(4), 81-94.

Vonshak A., Cohen Z. \& Richmond A., 1985. The feasibility of mass cultivation of Porphyridium. Biomass, 8, 13-25.

Xia L. et al., 2014. Selection of microalgae for biodiesel production in a scalable outdoor photobioreactor in north China. Bioresour. Technol., 174, 274-280

Yamani E. et al., 2009. Intérêt de la spiruline chez les personnes vivant avec le VIH à Bangui (RCA). Med. Trop., 69(1), 66-70.

Yao C.-H., Ai J.-N., Cao X.-P. \& Xue S., 2013. Salinity manipulation as an effective method for enhanced starch production in the marine microalga Tetraselmis subcordiformis. Bioresour. Technol., 146, 663-671.

(49 ref.) 